

$$
\begin{aligned}
& \text { رئيس التحريز } \\
& \text { أ.د/ أميرة أحمد يوسف سليمان } \\
& \text { عميدة كلية البنات للآداب والعلوم والتربية }
\end{aligned}
$$

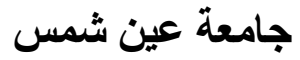

$$
\begin{aligned}
& \text { نائب رئيس التحرير } \\
& \text { أ.د// حنان محمد الثاعر } \\
& \text { وكيلة كلية البنات للار اسات العليا والبحوث } \\
& \text { جامعة عين شمس لاتس البن } \\
& \text { مدير التحريز } \\
& \text { أ.م.د/ أسماء فتحي توفيق }
\end{aligned}
$$

أستاذ علم النفس المساعد بقسم تربية الطقل

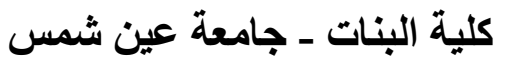

$$
\begin{aligned}
& \text { المحرر الفني } \\
& \text { أ.نور الهدي علي أحمد } \\
& \text { سكرتير التحرير } \\
& \text { نجوى إبراهيم عبا رباه عبد النبى لئي }
\end{aligned}
$$

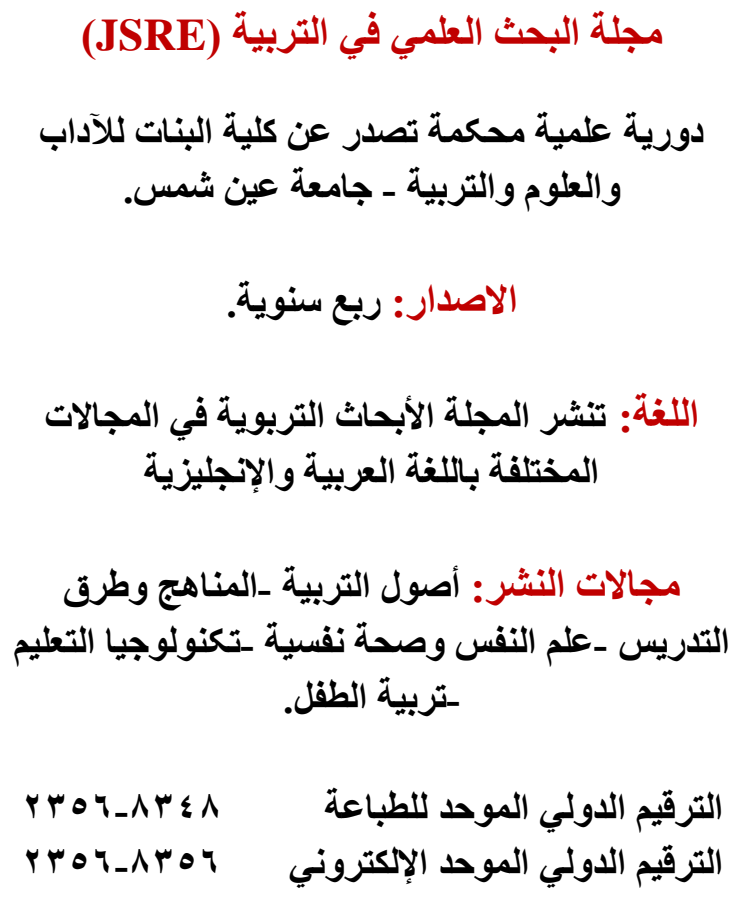




\title{
Higher Education's Leadership Soft Skills Reflected in Covid-19 Responses
}

\author{
DR. Mossab Saud Alholiby
}

\begin{abstract}
:
The 2020 coronavirus pandemic and its negative consequences have become the world's most unpredictable health crisis, thereby causing the global higher education community significant challenges. Because leaders of higher education institutions have responded to the Covid-19 crisis in various ways, this study's purpose was to gather information on methods and strategies of institutional leadership and management. The study uses desk and meta-analysis, researching specifically through a review of previous research and then deriving conclusions and recommendations. The two research questions are (1) how are universities responding to the pandemic? and (2) How has the pandemic impacted university leadership? Through skilled leadership, instructors and students have mostly shifted to online distance learning. Conclusions focus on the fact that higher education leaders should prioritize safeguarding of learners' rights and promote economic growth, sustainable development, and long-lasting peace. Therefore, leading decision-makers should heed the several recommendations in regard to guaranteeing the safety of all, ensure inclusive reopening, involve all stakeholders, remove connectivity limitations, and upholding the teaching profession and teachers' preparedness and management styles.
\end{abstract}

Keywords: COVID-19 pandemic, skilled leadership, higher education, online learning, crisis leadership, pedagogy

\section{Introduction}

The coronavirus pandemic has brought unexpected changes to people's lives worldwide, and the educational landscape is no different. According to the United Nations Educational, Scientific, and Cultural Organization (UNESCO, 2020), the COVID-19 pandemic declaration has prevented over a billion young people from attending in-person classes due to educational institutions' forced closures in 165 countries. Considering the unparalleled uncertainty of this pandemic, higher education leaders of colleges and universities have been forced to analyze problems and create solutions for the educational community even as they formulated immediate responses and longer-term management plans.

\footnotetext{
* Department of Educational Leadership, King Faisal University, Saudi Arabia. Email: Malholiby@kfu.edu.sa

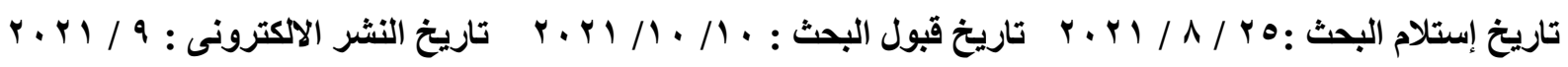


During December 2019, Wuhan, China reported 27 pneumonia cases with no clear cause, but in early 2020, that cause was discovered to be the novel coronavirus. At the end of March 2020, the World Health Organization (WHO) declared coronavirus 2019 a pandemic.

Fortunately for education, however, data connectivity can lead to the choice or requirement of (home) online study. As a consequence, however, the higher education community has been and still is challenged to develop an adequate online educational landscape (Casanova \& Price, 2018). With government guidance and support staff's help, higher education leadership has responded diversely to facilitate learning during the constant, ongoing changes of the pandemic. This article explores and examines universities' worldwide responses so far via desktop and meta-analysis of various countries' leadership approaches. Thus, the article seeks to answer the following two research questions: How are universities responding to the pandemic? How has the pandemic impacted university leadership?

The spread of coronavirus has effected changes in the higher education sector, especially in its operations (UNESCO, 2020). Therefore, this study focuses on organizational agility, especially in the transition to an online environment. Furthermore, it demonstrates effects on poorly-resourced institutions and on socially-disadvantaged students by such institutions' leadership strategies. Overall, the study is relevant to the examination of universities' preparation for the already-forthcoming digital era. More specifically, the article explores global leadership's approaches, responses, and experiences with Covid-19, providing an effective platform for benchmarking leadership skills, especially during a crisis. It is hoped that the recommendations arising from this article will support the leaders when choosing appropriate approaches of managing the impact of health crises such as Covid-19 on the issues of education, scientific research, medicine, culture and society.

\section{Methodology}

This article adopted desktop analysis and meta-analysis approaches while carefully considering the standards of the information source. For efficient and rapid status updates on global universities, using reliable, high-quality sources, especially considering the flux of Covid-19 information, is absolutely crucial. In the interests of transparency, this research accessed 28 sources, emphasizing primary university and government sources, supplemented by related articles. Information from nations whose language is not English required translation support from other authors. The article focused on leadership skills and responses across global regions, and its aim was to provide recommendations for digital pedagogy strategies and benchmark platforms for leaders from other areas.

\section{Literature Review}

As crucial actors in higher education management and administration, leaders come with varied skills and skill levels and from diverse professional and educational backgrounds (Tolman \& Calhoun, 2019). Certainly, leadership styles and competencies differ, but all university leaders work in a harsh, rapidly changing and demanding educational environment. 
Therefore, this article briefly explores the theory of practice and crisis leadership in higher education institutions worldwide under the impact of Covid-19.

\section{Crisis Leadership}

Crisis leadership means managing an organization throughout the response to an emergency or a disaster - an essential skill and a seriously increased responsibility for university leaders, especially during the Covid-19 pandemic (Fernandez \& Shaw, 2020). As Fernandez and Shaw (2020) emphasize, the pandemic has necessitated leaders to express their skills in dealing with such times. The global scope of the spread of the pandemic and its extreme impact has not allowed leaders the time to benchmark what others are doing; rather, it has required them to innovate and act fast. Crises are considered beyond human control, and what matters is appropriate mitigating responses to certain, often previously unknown challenges as they arise (Berjaoui \& Karami, 2019; Koehn, 2020). Leaders often cultivate multiple skillsets to deal with both internally and externally emerging issues; this has been an opportunity for them to actualize their skills. Somewhat optimistically, Warrick et al. (2011) highlight crises as ideal opportunities for transformative leadership skills to emerge. During difficult situations, the gift of crisis leadership presents itself in ways that showcase a leader's emerging capabilities. The institution needs leaders who can manage crises, and despite all the difficulties, they remain loyal to their institution, and can transfer their positive perspectives to the staff around them.

\section{Communication}

In addressing the pandemic, communication is probably the most critical skill university leaders need to keep the educational process continuing as smoothly as possible. Leaders' crisis communication with faculty, staff, students, and other stakeholders must be frequent, factual, concise, and timely (Fernandez \& Shaw, 2020). Leaders also need to project calm and collected behavior focused solely on conveying information compassionately and efficiently (Mackert et al., 2020). In the Information Age, good communicators should use both synchronous and asynchronous techniques to keep all groups informed and engaged (Watts, 2016).

\section{Adaptability}

Everybody loves it when events occur according to plan. But when unexpected events do occur, plans must be rethought, often rapidly (Yuki \& Mahsud, 2010). College and university leaders thus need to be flexible and nimble in adapting to and addressing crises. In this case, by thoroughly understanding the Covid-19 pandemic (Fernandez \& Shaw, 2020), they can develop approaches with help from varied and diverse perspectives, for instance, from the WHO, other international and other countries' health organizations and ministries, educational ministries and organizations, and associated higher education institutions. 


\section{Self-Control}

Despite the pandemic's abrupt onset, university leaders should avoid becoming frantic, and disorganized (Wang et al., 2020). Instead, they should be keen and assertive to avoid falling into the pandemic's grip. Even during a crisis, self-control helps enable rational decisions, effective communication, and efficient work. Especially in this case, self-control includes appropriate self-care and the modeling of self-care, especially for young adult students.

\section{Relationship Management}

University leaders should take special care to maintain positive relationships with all stakeholders by being friendly yet assertive (Wang et al., 2020). Excellent rapport (with selfcontrol) takes leadership in the right direction without the need for dictatorial rules (Dopon et al., 2016). During the pandemic, win-win leadership attitudes can facilitate a continued learning process.

\section{Creativity}

An unexpected crisis always disrupts current plans, so university leaders must think rapidly and critically about how to formulate new techniques and strategies to continue educating students. Composed leaders worldwide have quickly fostered creative solutions through teamwork, and they continue to initiate more flexible, safe strategies (Fernandez \& Shaw, 2020). Leaders are rising to the occasion, demonstrating agile competencies that provide effective communication and moral leadership that fosters return to significant shortterm achievements and normalized learning goals.

\section{Flexible and Adaptive Leadership}

Flexible and adaptive leadership entails appropriate changes to leadership behavior during rapidly evolving situations (Yuki \& Mahsud, 2010). Since COVID 19's emergence, higher education institutions have become more flexible, adaptive, and innovative in management and administration, especially toward the university workforce.

The reality of Covid-19's onset and spread, together with its unpredictability, has left everyone vulnerable, thus necessitating a malleable leadership approach (Fernandez \& Shaw, 2020). Research from previous contingency theories of leadership and from survey methods indicates that flexible and adaptive leaders, including those in higher education, follow specific guidelines of modern paradigms. Good leaders clarify specific roles, standards, and priorities for individual subordinates, eliminating ambiguity. Such clarity can help leaders monitor status and progress and, in higher education, effect valuable learning.

Effective leaders educate and model reasons for adapting to their formulated changes by appealing to the feelings and values of faculty, staff, and students, for instance, the critical need to maintain physical and social distance even from people emotionally close to them.

Additionally, leaders provide incentives for an intentional and successful learning process.

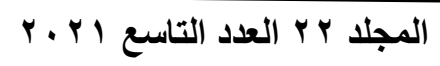$$
\text { مجلة البحث العلمي في التربية }
$$ 


\section{Crisis Management}

Crisis management involves sequencing stages: signal detection, preparation, containment, recovery, learning, and redesign. As the world attempts to keep pace with these stages of the Covid-19 pandemic, the education community's leadership also attempts to keep pace with the rest of the world (Mascolo, 2020). In managing and maintaining learning processes amid the pandemic, crisis management is crucial. Since crisis management involves an individual organization's learning, change, and performance at all levels, institutions of higher learning should have the unique capacity to continue and develop learning processes, along with better crisis management abilities.

\section{Change Management Principles}

In the relatively recent past, colleges and universities have adopted certain management principles to help deliver more desirable outcomes (Meerow \& Woodruff, 2020). Similarly, during the Covid-19 crisis, top administrators have adopted new leadership styles and management approaches that can provide realistic and safe learning outcomes.

\section{Beginning with the end in mind.}

Leaders at higher education institutions have designed initiatives with knowledge of their goals - practical learning and assessment within a contained-infection environment. Aligning their goals and equally considering all affected parties have so far helped shape strategies yielding considerable success.

\section{Understanding the culture of the institution.}

Leaders have become even more aware of their institutions' existing pre-pandemic cultures. Thus, after careful consideration of desired behaviors, different institutions in different countries have developed culturally-friendly solutions for their staff and students (Wang et al., 2020). Even amid the Covid-19 crisis, leaders' awareness connects with employees and students' hearts, provoking positive change and alignment with their goal, that is, safe continuation of effective learning.

\section{The ways of understanding the needs of stakeholders have changed.}

College and university leadership have considered differences among stakeholder groups, attempting to be as realistic as possible for each one (Lalli et al., 2020). For instance, does communication reach all international students? Can all students access online-learning opportunities, especially in underdeveloped countries? Certainly, every country and institution is implementing effective strategies for both learning and safety. Embracing relentless incrementalism while creating win-win aligned incentives helps achieve positive results from institutions' leadership. Leaders begin with goals, set measures for outcomes, and objectively monitor successes. They ask, "How well is the educational process going, and, at the same time, how well is the virus contained?" 


\section{Institutional Response to the Covid-19 Crisis}

Educational leaders monitor and evaluate the confusion that the coronavirus causes students worldwide by considering social distancing, campus closure and partial closure, lockdowns, quarantines, and travel restrictions, in order to implement response strategies (Jahagirdar et al., 2020). This remains difficult because, since the pandemic's declaration, impacts of the virus on students' study plans have repeatedly changed.

\section{Challenges Faced by Institutions during the Covid-19 Crisis.}

The Covid-19 pandemic has caused deep uncertainty and strain to higher education institutions navigating the crisis and maintaining course delivery. Keeping students, staff, and faculty safe while learning how to continue operations presents significant challenges (Brammer \& Clark, 2020). Additionally, forced and hurried movement from traditional education to e-learning has posed an enormous challenge, especially in practical courses and training (Osmond-Johnson, Campbell, \& Pollock, 2020; Ratten, 2020). Effective communication and continuity of planning to keep students and staff safe while avoiding panic are the education community's most common challenges.

\section{The Educational Approaches Adopted by Universities during the Coronavirus Pandemic.}

Trying to espouse a constantly changing "new normal," college and university leadership has implemented a new range of measures to harmonize the virus and steady institutions' activities (Brammer \& Clark, 2020). Rising concern about the virus has necessitated that leaders formulate workable course delivery and protective plans for all groups at their institutions. Below are various tactics adopted by leaders to facilitate learning despite of the challenges of the pandemic.

Institutions have transferred most scheduled courses to online formats. For instance, by mid-March 2020, Harvard University in the United States moved all systems online and required all students to move off campus. In another approach, Arizona State University in the United States moved classes online but kept campus facilities operating.

Advancing levels of online educational delivery poses challenges in the best of times, but doing so abruptly and completely under far-from-ideal conditions has been extraordinarily demanding for all stakeholders (IAU, 2020). Institutional leadership has considered such strategies' pros and cons but focused on its main goals - adaptive and flexible leadership that keeps students and staff safe while continuing learning operations.

Some institutions delayed start dates for some courses for an entire semester. In response to the government's Covid-19 restrictions, Australia University rescheduled the university calendar and moved examinations online (IAU, 2020). Additionally, staff facilitating learning and examinations and students were allowed to choose venues, thus eliminating travel requirements. Swinburne University in Australia delayed the start of its succeeding semester to 2021, to prioritize students' safety and health. In doing so, the 
administration portrayed empathy and self-control by maintaining a calm environment while students await their studies' resumption. Other institutions simply deferred student applications and offers to 2021. But because most institutions require student revenue to operate (Longhurst, 2020), they are accepting that after enrolling few students, their income might decrease significantly in the succeeding academic year. However, this necessary compromise means that institutions are more likely to maintain their intake numbers and recover from today's insufficient revenue.

To ensure the best coverage possible, academic leadership has strategically updated communications with international students via different platforms. Leaders have emphasized the importance of online learning and training students in online tools' capabilities, reassured them, and promptly addressed their concerns (Casanova \& Price, 2018). Because a personalized touch brings about international students' satisfaction and retention, leadership has used these strategies to prevent students from deferring their education or transferring to schools in their own countries.

In general, higher education leaders worldwide have displayed the following creative approaches in crisis management:

Online distance learning

International coordination and collaboration

Application of strict and compulsory sanitation initiatives (e.g., regular handwashing, wearing facemasks during all public encounters)

Clear communication from university leadership and administration

Proactive preventive measures (e.g., sanitizing facilities, taking temperatures)

Flexible and adaptive student assessment and examinations

Reliable and robust university leadership

\section{Higher Education Institutions Embrace Online learning, Distance learning and Blended learning.}

After the impact of COVID-19, online, distance and blended learning were becoming widely used as teaching methods. It is perhaps easier to consider the terminology as defining a range of teaching methods. The online learning method is where all the course material is provided online through the web . Recorded lectures, videos, study guides, and activities might all be included in the material. The student studies the course content at his own pace, whenever he has time and Internet connection, utilizing his mobile, tablet, or computer. (Park \& Shea, 2020, Das, 2021, Al-Hunaiyyan, Alhajri, \& Bimba, 2021).

Distance learning is a broader term which refers to studying remotely from the university. Online learning is technically a form of distance learning, but the term is more commonly used to refer to courses where the teachers are separate from the students. Distance learning course content is delivered online. It includes the same content as online learning, but with the addition of live lectures on scheduled times and dates that students are required to attend. Students will be able to participate during the lecture by using group participation 
platforms such as Zoom, blackboard and Microsoft Teams. Lessons are usually recorded for future reference (Das, 2021, Al-Hunaiyyan, Alhajri, \& Bimba, 2021).

Blended learning combines classroom teaching with online learning. Instructors teach courses face to face in a classroom and course materials are available online. In this case , students can study the relevant content prior to the face-to-face session and then follow up on it afterwards (Das, 2021, Al-Hunaiyyan, Alhajri, \& Bimba, 2021).

With replacement of in-person classes, students have adapted to new learning methods that favor most students across the globe (Martin et al., 2017). However, the inconvenient reality is that low- and middle-income countries might provide only low or no household Internet connectivity (Roache et al., 2020). Traditional education among classmates and teachers seems to be the most appreciated learning method, and a rapid, radical shift to a new online-learning environment requires students to do a little more than usual.

In general, the change to online learning methods does not seem to have been positively received. One reason is that lesson content and teaching methods were not initially designed for non-proximity. Second, online learning requires some level of commitment from students; this most likely explains why it is more efficient among postgraduates (older people) than undergraduates (Adnan, 2020; Gonzalez et al., 2020). Moreover, the face-to-face experience is incredibly important for less advantaged students because university facilities often aid them in developing more sophisticated social skills. Thus, online learning can lengthen and intensify previous student disadvantages.

Foreseeing impacts of learning modality changes on students and leaders is quite difficult, if not impossible. In standard cases, traditional dynamics are generated from technological means; therefore, the effect should not be significant (Asamoah-Boateng, 2020). Returning to the classroom will likely be experienced as resuming normalcy. However, it is essential to consider that instructors and students might experience doubts about returning to the classroom mode without having completely exploited the e-learning mode's opportunities.

The most impenetrable question is whether students will achieve courses' learning goals through online learning methods. Existing research shows that results should be approximately equal, particularly when of short duration (Yen et al., 2018). Nevertheless, when variables are of a broader context, assuming that results will be identical is open to doubt.

\section{University Responses in Various Regions of the World}

Four countries were selected to explore its leaders' responses to the impact of covid19, namely: Australia, China, Germany and Nigeria. These countries have obvious differences in the aspects of language, culture, available resources, economy and education systems. This helps in discovering the differences and similarities more clearly between the responses of leaders in those countries, identifying the soft skills that emerged in the crisis, and identifying 
the models and curricula that were developed to ensure the continuity of education despite difficult circumstances.

Australia. Australia's higher education system has responded to the COVID-19 pandemic with varying effectiveness. The leadership of education first addressed international students' concerns due to travel restrictions and local cases requiring isolation. At the university management, rapid cleaning and sanitizing of physical plants were implemented. Furthermore, the majority of universities have opted for alternative learning methods. However, some have decided to retain face-to-face learning with social distance protocols in place (University of Adelaide, 2020). The Australian government has banned public indoor gatherings exceeding 100 individuals, and this ban is likely to influence significantly universities that did not change to e-learning.

China. China suffered the first case of COVID-19, so the higher education sector had little time to prepare, and various reports on response speeds do not coincide. Some conclude on an early February 2020 transition, while others indicate mid or late February (McKenzie, 2020; Crawford et al., 2020). Regardless, they took time because the gravity of the virus was not yet clear to the rest of the world. Scientists were also grappling with the novel virus, unsure of whether it was something the world could deal with as with other corona viruses. The leadership adopted online learning in March 2020, but not all institutions have the necessary resources to facilitate e-learning (Leung, 2020). Overall, schools are open with strict restriction protocols to enable all students a high-quality learning experience.

Germany. Germany was one of the earliest (March 2020) and most affected countries (Statistica, 2020), and the University of Passau exemplifies various university leadership's rapid and rigorous approach. For instance, it immediately transferred all oral examinations to Skype, FaceTime, and other digital means. State government imposed a comprehensive lockdown. School management "evicted" students residing on campus, and inactivated all their electric identification (Crawford et al., 2020). Meantime, preparations for virtual learning are ongoing. While leaders could institute new measures at a fast pace, the pandemic was being handled from top governmental levels, and new rules were implemented through these measures. As the government issued a lockdown, it was unclear during the initial days whether schools could resume soon in their traditional way. Based on the understanding that the COVID-19 control measures could last longer, countries like Germany opted for alternative methods of learning.

Nigeria. Nigeria initiated proactive measures, such as all airports' closure, after reporting 22 Covid-19 cases in March 2020. The National Universities Commission ordered closure of all universities (Crawford et al., 2020), and fast-tracking of ongoing examinations was advised for the end of March. The government also issued a one-week lockdown of Lagos, the country's most dynamic city. The spread of COVID-19 was gradual, and the country had to work with its situation as new information regarding the virus emerged. Nigeria could also benchmark from other nations that had closed their institutions of higher learning before and instituted social distancing. Nonetheless, the spread of the pandemic and 
testing in Nigeria, and Africa in general, was relatively low, which could downplay the impact.

The meta-analysis of four countries across continents shows apparent similarities and differences in approaches and leadership skills. Change from traditional to online learning cannot be achieved overnight because of the associated challenges and the uncertainty of unanswered questions, such as how students from remote settings can gain access to online learning (Quezada, Talbot, \& Quezada- Parker, 2020) and what are the general skills required for professional online delivery, just to mention a few. The analysis highlights that online learning effectiveness is directly proportional to the institution's available resources and the country. Most of the learning facilities are closed and focused on transitioning to online learning and pedagogy. Practicing principles of online training has never been undertaken as a collaborative and collective global response (Roache, Rowe-Holider \& Muschette, 2020). A global pandemic can be a cause for pooled resources and expertise worldwide to make sure that education for all students keeps going even in the face of COVID-19.

\section{Leaders' Support of Faculty and Other University Employees}

All leaders in higher education have a duty to support their subordinates, and to do so during the Corona crisis, they have used different approaches. One is accessing reputable sources such as UNICEF or WHO for reliable, accurate information on Covid-19's transmission and prevention. Another is planning appropriate responses to possible and confirmed Covid-19 cases and addressing potential issues such as stigma. Furthermore, leaders have promoted information sharing with staff and considered their physical and psychosocial support needs while working. Moreover, leaders have given vulnerable staff members special consideration. Such administrative support enables all employees to conduct their assigned roles in a well-informed manner.

\section{Discussion}

Since Coronavirus burst upon the global scene, higher education institutions have been under great pressure: to transition immediately to online education due to lockdowns; to cope with lack of international mobility due to travel restrictions (Toquero, 2020); to close or partially operate research facilities whose activities are not related to Covid-19; and to protect the physical and mental safety and well-being of faculty, staff, students, and other stakeholders. In providing findings and discussions of higher education leadership during the Covid-19 pandemic, this article covers the following topics of education, research, internationalization, societal engagement, and university governance.

\section{Education}

Emergence of the Coronavirus has led to learning transition from traditional to online. However, online teaching presents various challenges: First, not all students can access a computer or Internet connection to follow online classes and complete assignments. 
Second, for lecturers and students to combine professional and family duties while teaching and learning from home is difficult. And last, ascertaining whether students are following online courses properly is not easy (Toquero, 2020). Therefore, higher education leadership has implemented follow-up to ensure students have pursued their online studies appropriately, facilitated funding for suitable equipment, and increased the number of staff while training staff members in new methodologies.

\section{Research}

Covid-19 researchers have received intense governmental and social attention while being seriously consulted on various decisions likely to affect a particular state (Toquero, 2020). However, non-Covid-19 related scientists have difficulties accessing libraries, museum collections, laboratories, and travel to gather data. Furthermore, international conferences, collaborative research, and meetings have been postponed, hindering the usual networking and ongoing projects.

\section{Internationalization}

Students who were abroad when the lockdown was introduced, especially international students, have been significantly affected. They have suffered major challenges including lack of one-to-one interaction, different time zones, and inadequate information technology infrastructure for online classes (Toquero, 2020). Higher education institutions have variously tackled these challenges by organizing virtual cafes for international students to stay in contact with local students, by introducing online intercultural training to bring people together, and by funding electronic devices for some students in need. Moreover, universities have also introduced websites and website sections with critical information for students from abroad.

\section{Societal Engagement}

Societal engagement means university participation in other than educational sectors or contribution by creating cultural knowledge. Since the Covid-19 pandemic outbreak, higher education institutions have tried their best to provide for their communities from where they are based (Toquero, 2020). Various societal engagement initiatives include introducing volunteering schemes to help the needy and the elderly (for example, distributing food, teachers raising awareness of Covid-19, and distributing facemasks and hand sanitizers). Second, university professors have created public webinars for analysis of Covid-19, including factual information, implications of the pandemic, and so on. Lastly, researchers, especially engineers and medical students, have pooled their knowledge to develop pulmonary ventilators and Covid-19 test kits when these tools were scarce.

\section{University Governance}

University leaders are faced with tough decisions when countries have decided to close buildings as health safety measures. Even with already-ongoing governance restrictions, 
university leaders have accomplished the following: established special task forces to assess the pandemic situation and then report to and advise the president on measures to be undertaken; placed entry and exit indicators at institutions and buildings or rooms' entryways; provided easily accessible sanitizers, automated thermometers, handwashing facilities, and facemasks; and directed social distancing measures. Last, universities are investing in various other support structures, for instance, testing and health facilities, to protect students' wellbeing.

\section{Conclusion}

The Covid-19 crisis unexpectedly shocked educational institutions, hindered achievement of universal educational goals, and caused significant negative effects to the most vulnerable. However, university leaders have so far played a vital role in meeting these and other challenges, with rapid transition to online learning as their most obvious achievement. Indeed, the learning curve has been steep, but the forced transition is likely to foster substantial permanent change.

This article's first part outlined leadership's actions and strategies to maintain effective and ongoing courses. The second part highlighted various changes to facilitate efficient and equitable learning. Furthermore, the Covid-19 crisis has revealed opportunities for positive change, for instance, joining forces to network and sharing international knowledge and expertise to overcome the pandemic's negative impact.

Clearly, worldwide higher education leadership has joined forces to explore opportunities for transforming and improving the educational sector despite the Covid-19 pandemic.

\section{Recommendations}

Higher education leaders should prioritize safeguarding of learners' rights and promote economic growth, sustainable development, and long-lasting peace. Therefore, leading decision-makers should heed the following recommendations. It is important to consider that the approaches that are already being followed are excellent and that a combination of various options can lead to the realization of these recommendations.

\section{Guarantee the Safety of All}

Higher education leadership should formulate guidelines to help institutions recondition their physical plants and time their reopenings. Maintaining social distance safely and following governmental and medical institutions' health safety measures, such as handwashing and wearing masks, are critical. This might prove difficult in overcrowded classes and require additional investment in infrastructure.

\section{Ensure Inclusive Reopening}

In formulating reopening strategies, leaders should carefully include the needs of marginalized students, and sufficient health measures should be provided for special-needs 
students. Additionally, learning gaps should be assessed and remedial classes prepared to speed programs after institutions reopen.

\section{Involve all Stakeholders}

Since Covid-19's outbreak, instructors, parents, and custodians, in consultation with internal and external stakeholders, have played essential roles in making decisions about reopening. Higher education leaders should ensure clear communication of planning proceedings with stakeholders to avoid students' decreased chances of resuming studies.

\section{Remove Connectivity Limitations}

The Covid-19 crisis shed light on the digital barrier and other equity gaps that need urgent attention. Universities and governments need to form various partnerships to remove connectivity barriers by devoting resources toward digital infrastructure and reduced Internet costs. In turn, this will create the need to invest in marginalized communities' digital literacy.

\section{Coordinate with the Health Community}

Leaders in higher education are recommended to collaborate closely with the professional health community while formulating strategic approaches to resuming normal learning operations (Mackert et al., 2020). Furthermore, they should reflect on reopening policies through available international information, observations, and experiences.

\section{Uphold the Teaching Profession and Teachers' Preparedness}

Teachers and communities should be adequately prepared and supported for equitable and all-inclusive learning in- and outside classrooms. Equipping teachers with online and e-learning instructional skills is essential, but of more importance is ensuring that they possess pedagogical and evaluation skills to execute an accelerated curriculum and the various learning strategies that might emerge during the teaching and learning process.

\section{Management Styles}

For efficient and effective management, higher learning leadership should adopt electronic management and services. This dual-mode approach allows use of existing institutional staff and facilities to reduce rehiring and training costs, to accomplish management tasks, and to facilitate learning's continuity.

\section{References}

Al-Hunaiyyan, A., Alhajri, R., \& Bimba, A. (2021). Towards an Efficient Integrated Distance and Blended Learning Model: How to Minimise the Impact of COVID-19 on Education. International Journal of Interactive Mobile Technologies, 15(10), 173-193. https://doi-org.sdl.idm.oclc.org/10.3991/ijim.v15i10.21331 
Asamoah-Boateng, C. (2020). Ghana Association of University (GAUA) @ 40: A historical perspective. GAUA Newsletter, 2(1), 6-7.

Berjaoui. R. R., \& Karami-Akkary, R. (2019). Distributed leadership as a path to organizational commitment: The case of a Lebanese school. Leadership and Policy in Schools. https://doi.org/10.1080/15700763.2019

Brammer, S., \& Clark, T. (2020). COVID-19 and management education: Reflection on challenges opportunities, and potential futures. British Journal of management, 31(3), 453.

Casanova, D., \& Price, L. (2018). Moving towards sustainable policy and practice-a five level framework for online learning sustainability Canadian Journal of Learning and Technology/La revue Canadienne del apprentissage et de la technologie, 44(3).

Crawford, J., Butler-Henderson, K., Rudolph, J., Malkawi, B., Glowatz, M., Burton, R., ... \& Lam, S. (2020). Covid-19: 20 countries' higher education intra-period digital pedagogy responses. Journal of applied Learning \& Teaching, 3(1), 1-20.

Das, R. (2021). The Attitude of Students and Teachers Towards Blended Learning at the Elementary Level. Ilkogretim Online, 20(5), 245-257. https://doiorg.sdl.idm.oclc.org/10.17051/ilkonline.2021.05.23

Dopson, S., Wilson, S., Ferlie, E., McGivem, G., Fischer, M. D., Ledger, J., \& Behrens, S. (2016). The impact of leadership and leadership development in higher education. A review of the literature and evidence (Research and Development Series). Education administrators. Georgia Journal of College Student Affair, 75C1). 63-8N MITED

Fernandez, A. A., \& Shaw, G. P. (2020). Academic leadership in a time of crisis: The coronavirus and COVID-19. Journal of Leadership Studies, 14(1), 39-45.

Gonzalez, T., de la Rubia, M, A., Hinez, K. B, Comas-Lopez, M., Subirats, L., Fort, S., \& Sacha, G. M. (2020). Influence of COVID-19 confinement on students' performance in higher education. PloS One, 15(10), e02394920

IAU, (2020). The impact of Covid-19 on higher education worldwide. Online International Interdisciplinary Research Journal, VI(D). 303-309.

Jahagirdar, S. Chatterjee, A Bchera, S., \& Mohapatra, A. (2020). Response to the COVID19 pandemic in India: Case studies on leadership in crisis situations. International Journal Health \& Allied Sciences, 9(5).81-84.

Koehn, N. (2020). Real Leaders Are Forged in a Crisis. Harvard Business Review, Retrieved from https://hbr.org/2020/04/real-lcaders-are-forged-in-crisis 
Lalli, G., Defeyter, G., Shinwell, J., von Hippel, P., Henderson, E., Brownlee, I., ... \& DalySmith, A. (2020). Back to school post COVID-19: Rebuilding a better future for all children.

Leung, C, C., Lam, T. H., \& Cheng, K, K. (2020). Mass masking in the Covid-19 epidemic: people need guidance. Lancet, 395(10228), 945.

Longhurts, G. J., Stone, D. M., Dulohery, K., Scully, D., Cambell, T., \& Smith, C. F. (2020). Strength, Weakness, Opportunity, Threat (SWOT) analysis of the adaptations to anatomical education in the United Kingdom and Republic of Ireland in response to the Covid-19 pandemic. Anatomical Sciences Education, 13(3), 301-311.

Mackert. M., Table, B., Yang. J., Bouchacourt. L. Woods. J. M. Bermhardt, J, M., \& Wagner, J. H. (2020). Applying best practices from health communication to support a university's response to COVID-19. Health Communication, 1-4.

Martin, F. Polly, D., Jokiaho, A., \& May, B. (2017) Global standards for enhancing quality online learning. Quarterly Review of Distance Education, 18(2) 1-102

Mascolo, M. (2020). Transforming higher education: Responding to the Coronavirus and other looming crises. Pedagogy and the Human Sciences, 7(1), 2.

Meerow, S., \& Woodruff, S. C (2020). Seven Principles of Strong Change Planning. Journal of the American Planning Association, 86(1), 39-46.

Osmon-Johnson. P. Camphel. C., \& Pollock, k. (2020) Moving Forward in the COVID-19 Era: Reflections for Canadian education. Education Canada Network. Retrieved from https://www.edcan.ca/articles/moving-forward-in-the-covid-19-era.

Park, H., \& Shea, P. (2020). A Review of Ten-Year Research through Co-Citation Analysis: Online Learning, Distance Learning, and Blended Learning. Online Learning, 24(2), 225-244.

Quezada. R. L., Talbot, C., \& Quezada-Parker. K. B. (2020) From bricks and mortar to remote teaching a teacher education programme's response to COVID-19, Journal of Education for Teaching, 1-12.

Ratten, V. (2020). Coronavirus (Covid-19) and the entrepreneurship education community. Journal of Enterprising Communities People and Places, in the Global Economy. https://doi.org/10.1108/JEC-06-2020-0121

Roache, D., Rowe Holder, D., \& Muschette, R. (2020) Transitioning to online distance learning in the COVID-19 era: A Call for Skilled Leadership in Higher Education Institutions (HEIS). CCEAM, 103. 
Tolman, S., \& Calhoun. D. W. (2019). Pedagogical approach to developing the hiring practices of higher education administrators, Georgia Journal of College Student Affairs, $35(1), 63-83$.

UNESCO (2020). Education: From disruption to recovery. Retrieved from https://en.unesco.org/covid19/

Wang. C., Yang, J., Cheng, Z., \& Ni. C, 2019. Postgraduate Education of Board Members and R\&D Investment Evidence from China. Sustainability, 11(22)6524.

Warrick. D. D. (2011). The urgent need for skilled transformational leaders: Integrating transformational leadership and organization development. Journal of leadership, Accountability, and Ethics, 8(5), 11-26.

Watts, L., (2016). Synchronous and asynchronous communication in distance learning: A review of the literature. Quarterly Review of distance Education, 17(1), 23-32.

Yen, S. C., Lo, Y. Lee, A., \& Enriquez, J. (2018). Learning online, offline, and in-between: comparing student academic outcomes and course satisfaction in face-to-face, online, and blended teaching modalities. Education and Information Technologies, 23(5). 21412153.

Yukl, G., \& Mahsud, R. (2010). Why flexible and adaptive is essential. Consulting Psychology Journal Practice and Research, 62(2). 81-93. 
انعكاسات جائحة كورونا على مهارات القيادة الناعمة في التعليم العالي

$$
\text { د. مصعب سعود الحليبي }
$$

أستاذ مساعد بقسم القيادة التربوية ـ كلية التربية ـ جامعة الملك فيصل

المستخلص:

أصبحت جائحة كورونا (كوفيد-9 (1) و عو اقبها السلبية من أكثر الأزمات الصحية التي لا يمكن

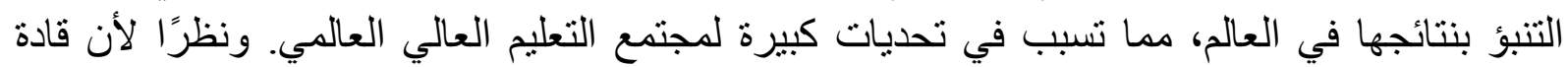
مؤسسات التعليم العالي قد استجابو الأزمة Covid-19 بطرق و أساليب متنو عة، لذا فإن الغرض فئم من هذه

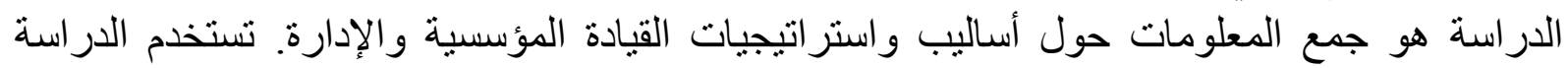
التحليل المكتبي والتحليل البعدي، والبحث على وجه التحديد من خلال مراجعة الأبحاث السابقة ثم

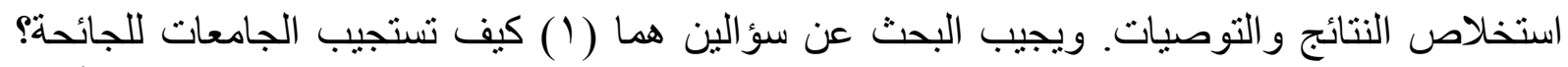

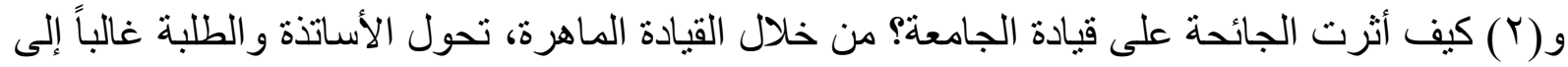

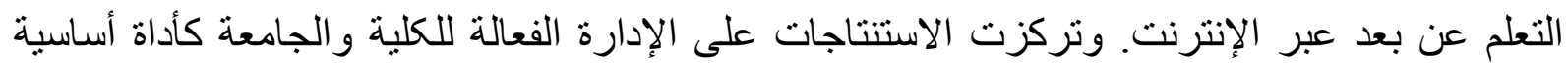

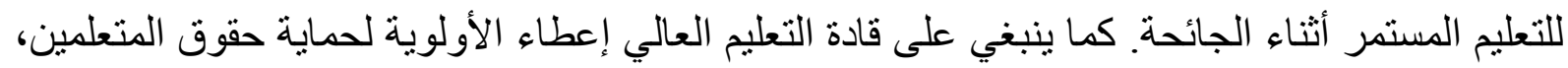

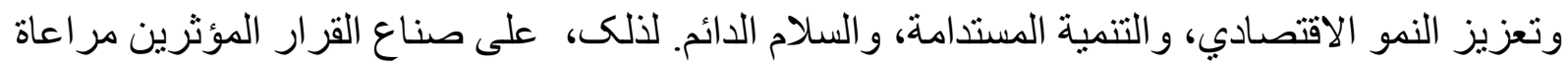

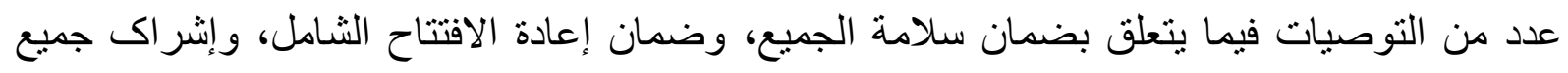

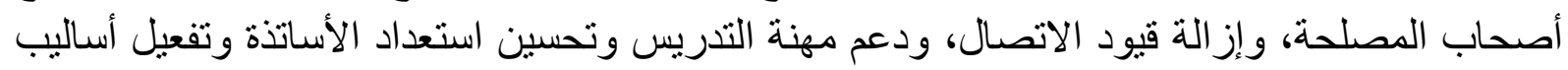
الإدارة الملائمة.

الكلمات المفتاحية: جائحة كورونا، مهار ات القيادة الناعمة، التعليم العالي، التعلم عن بعد، قيادة الأزمات

Received on: 25 /8 / 2021 - Accepted for publication on : 10/10/2021- E-published on: 9/ 2021 